\title{
Evaluating the potential of soil management to reduce the effect of Fusarium oxysporum f. sp. cubense in banana (Musa AAA)
}

\author{
R. A. Segura-Mena (ib • J. J. Stoorvogel • F. García-Bastidas • \\ M. Salacinas-Niez • G. H. J. Kema • J. A. Sandoval
}

Accepted: 4 March 2021 / Published online: 19 March 2021

(C) The Author(s) 2021

\begin{abstract}
Fusarium oxysporum f. sp. cubense (Foc) causes Fusarium wilt in banana (Musa $A A A$ ). Foc Race 1 devastated the subgroup Gros Michel during the first half of the twentieth century. The Gros Michel was largely replaced by the resistant subgroup Cavendish in the 1950s. However, in the 1980s, Foc Tropical Race 4 started to spread affecting Cavendish bananas. No proper control measures have been found to deal with the disease. This paper re-takes an important research line from the 1950s to evaluate the potential of soil management for Fusarium wilt management. The role of soil properties on Fusarium wilt in bananas was studied in two greenhouse experiments. It was evaluated whether the influence of two main soil properties $(\mathrm{pH}$ and $\mathrm{N}$ ) on Fusarium wilt is similar for Race 1 and Tropical Race 4. Two soil pH levels (lower than 5.2 and higher than 6.0) respectively ensured through acidification and liming; and three levels of $\mathrm{N}$ (ammonium nitrate, $33.5 \% \mathrm{~N}$ ) weekly doses (low:0 $\mathrm{N} \mathrm{g}$, medium:
\end{abstract}

R. A. Segura-Mena $\cdot$ J. J. Stoorvogel

Soil Geography and Landscape Group, Wageningen University, Wageningen, the Netherlands

R. A. Segura-Mena $(\bowtie) \cdot$ J. A. Sandoval

Research Center, CORBANA, PO Box 32-7210, Guápiles, Costa Rica

e-mail: rafael.seguramena@wur.nl

e-mail: rsegura@corbana.co.cr

F. García-Bastidas • M. Salacinas-Niez • G. H. J. Kema Biointeractions and Plant Health, Wageningen University and Research, Wageningen, the Netherlands
$0.08 \mathrm{~N} \mathrm{~g}$ and high: $0.25 \mathrm{~N}$ g per plant) were achieved. The first experiment in Costa Rica confirmed the earlier results about the influence of soil $\mathrm{pH}$ and nitrogen on Fusarium wilt (Race 1) on Gros Michel bananas. The second experiment in The Netherlands evaluated the influence of $\mathrm{pH}$ and $\mathrm{N}$ on interactions between Foc (both Race 1 and Tropical Race 4) and Cavendish bananas. Results in both experiments showed that soil $\mathrm{pH}$ affected crop development and the disease. Besides, the interaction of the lower $\mathrm{pH} \times$ the higher $\mathrm{N}$ accelerated the infection and reduced plant development. As such, the results showed that soil management has the potential to reduce the impacts of Fusarium wilt while dealing with Race 1 and Tropical Race 4 although it requires confirmation and further evaluation under field conditions.

Keywords Crop disease $\cdot$ Crop protection · Nitrogen . Plant nutrition $\cdot$ Panama disease $\cdot$ Soil fertility

\section{Introduction}

Fusarium wilt (also known as 'Panama disease') is a soil-borne disease caused by the fungus Fusarium oxysporum f. sp. cubense (Foc). The disease has strongly affected global banana production (Dita et al. 2018; Ordoñez et al. 2015; Pocasangre et al. 2017). Desert bananas and cooking bananas (including plantain) are an important staple in developing countries, where they represent a major part of the subsistence economy for millions of people (Aurore et al. 2009). In addition, 
desert bananas, dominated by the subgroup Cavendish (Musa AAA), are an important and valuable agricultural commodity for many exporting countries (Butler 2013; Ploetz 2015). The first major outbreak of Fusarium wilt (caused by the so-called Race 1 strain of Foc) decimated the large-scale production of the susceptible banana subgroup Gros Michel (Musa AAA). A gradual shift to resistant Cavendish (Musa AAA) cultivars controlled the epidemic in Latin America and the Caribbean during the last century (Harper 1950; Perez-Vicente 2004; Ploetz 1990; Stover 1961). This shift to Cavendish cultivars saved the banana industry. However, another Foc strain, commonly called Tropical Race 4 (TR4; Foc vegetative compatibility group VCG 01213), currently affects or threats Cavendish plantations worldwide.

Foc TR4 may lead to a new, more widespread, wave of Fusarium wilt, as many banana cultivars are susceptible to this strain (Molina et al. 2008; Ordoñez et al. 2016). Foc TR4 has been reported in various countries, such as Malaysia, China, Indonesia, and the Philippines in South East Asia (Molina et al. 2008), Jordan (García-Bastidas et al. 2014) and Pakistan (Ordoñez et al. 2016), where it already destroyed thousands of hectares. Recently, Foc TR4 has also been reported in Latin America (GarcíaBastidas et al. 2020). The potential effect of further dissemination could cause chaos, damage the economies of many banana-producing countries, and affect food security (Dita et al. 2013). There are no effective control measures (such as fungicides or cultural practices) for the disease. A transgenic TR4 resistant Cavendish cultivar (Dale et al. 2017) and somaclonal variation in resistance in Cavendish cultivars (Hwang and Ko 2004) are being promoted, but these options require more validation and studies before large-scale implementation. Given the fact that it takes several years to develop and distribute resistant banana cultivars, and the ineffectiveness of fungicides or other crop protection agents, it is appropriate to consider alternative strategies to reduce disease incidence in the short term (Geense et al. 2015).

Soil properties are known to influence the predisposition of crops to diseases (Doran and Zeiss 2000; Ghorbani et al. 2008; Huber et al. 2012) and they can be managed through e.g., fertilization, liming, tillage, and drainage. Therefore, soil management can potentially reduce the impact of crop diseases (Amir and Alabouvette 1993; Höper et al. 1995). Nevertheless, soil management receives little attention as a strategy for crop disease management. Although Rishbeth (1955) and Stover (1961) already discussed the potential of soil management in the case of Foc Race 1 in bananas, the research into soil management to control Fusarium wilt became less relevant with the discovery and introduction of Cavendish bananas. Problems with Race 1 in the small-scale production of susceptible varieties and the recent spread of Foc TR4 renewed the interest into soil management for Fusarium wilt management. Recently, several authors discussed the potential role of soil properties (e.g., pH, drainage, and nutrients) in relation to Fusarium wilt in bananas, mainly focusing on Fusarium wilt by Foc Race 1 (Domínguez et al. 2008; Geense et al. 2015; Haddad et al. 2018; Orr and Nelson 2018; Segura et al. 2018, 2019). The current threat of Fusarium wilt by Foc TR4 makes it necessary to corroborate the previous results obtained with Foc Race 1. However, despite the need for more insight in Foc TR4, it is practically impossible to carry out field experiments with Foc TR4 in most places around the world for phytosanitary reasons. As a result, many studies use Foc Race 1 and susceptible varieties under the assumption that these results are also valid for Foc TR4 (e.g., Bowen et al. 2019).

Literature confirms the effects of soil $\mathrm{pH}$ on crop disease incidence. A low soil $\mathrm{pH}$ has been linked with a higher predisposition to diseases in crops (Huber et al. 2012; Rengel 2000): Fusarium wilt in flax (Höper et al. 1995) and bananas (Domínguez et al. 2001), root rot (Aphanomyces spp.) in pea (Persson and Olsson 2000), common scab (Streptomyces scabiei) in potatoes (Goto 1985; Lacey and Wilson 2001; Lambert et al. 2005), and phytophtora root rot (Phytophthora cinnamomi) in avocado (Fernandez-Falcon et al. 1984). However, there are also examples that a high soil $\mathrm{pH}$ is associated with a higher crop disease incidence: black root (Thielaviopsis basicola), causing black root rot in tobacco (Harrison and Shew 2001; Oyarzun et al. 1998) and take-all (Gaeumannomyces graminis Sacc.) in wheat (Duffy et al. 1997). Despite these reports, where a relation between soil $\mathrm{pH}$ and the incidence of crop diseases was found, there are also other studies that did not confirm this relationship (Janvier et al. 2007).

It is generally accepted that soil $\mathrm{N}$ influences crop diseases (Huber et al. 2012; Janvier et al. 2007; Rengel 2000). However, the results are inconsistent and varied according to e.g., the applied $\mathrm{N}$ form, the pathogen, the crop or its growth stage (Dordas 2008; Harrison and Shew 2001; Huber and Watson 1974). Both positive and negative relationships between $\mathrm{N}$ concentrations and crop disease incidence have been reported. For 
instance, a lower $\mathrm{N}$ concentration was related with increased incidence of early blight (Alternaria solani) in potatoes (Miller and Rosen 2005), Xanthomonas wilt (Xanthomonas campestris pv. musacearum) in bananas (Atim et al. 2013), grey mould (Botrytis cinerea) in tomatoes (Hoffland et al. 1999), and bacterial speck (Pseudomonas syringae) and powdery mildew (Oidium lycopersicum) in tomatoes (Hoffland et al. 2000). N concentrations are especially important for disease incidence in wheat and other cereals. The incidence of takeall caused by Gaeumannomyces graminis (Brennan 1992), Septoria tritici blotch (Mycosphaerella graminicola), brown rust (Puccinia recondite), powdery mildew (Blumeria graminis) and foot rot (Fusarium spp.) increased with higher $\mathrm{N}$ concentrations (Leitch and Jenkins 1995; Olesen et al. 2003; Rodgers-Gray and Shaw 2000; Tiedemann 1995; Walters et al. 1984).

This paper aims to re-take an important research line from the 1950s to evaluate the potential of soil management to control Fusarium wilt in bananas. Based on the importance of soil $\mathrm{pH}$ and $\mathrm{N}$ in crop production and the reported impact of these soil properties on crop response to diseases their role on the expression of Fusarium wilt in bananas was studied. In addition, this study evaluates whether the influence of those soil properties on the occurrence of Fusarium wilt is similar for Foc Race 1 and Foc TR4.

\section{Materials and methods}

Two separate greenhouse experiments with a similar experimental setup were carried out. The first experiment, performed in Costa Rica, aimed to evaluate previous results about soil properties and the disease reported in the literature with the model between the subgroup Gros Michel and Foc Race 1 (present in Costa Rican soils). The second experiment, performed in The Netherland under strict biosecurity rules, aimed to study the effect of soil properties on the subgroup Cavendish and Foc TR4 to evaluate whether this new strain of the fungus provides similar results.

In the first greenhouse experiment (in Costa Rica), the development of Fusarium wilt by Foc Race 1 was studied. The aim was corroborating previous results reported in the literature about the incidence of Fusarium wilt in the model between Gros Michel banana and Foc Race 1. It was performed in the facilities of the CORBANA's Research Center (132 m.a.s.l., $10^{\circ} 15^{\prime} 54^{\prime \prime} \mathrm{N}, 83^{\circ} 46^{\prime} 26^{\prime \prime} \mathrm{W}$, minimum temperature of $17^{\circ} \mathrm{C}$ and maximum temperature of $35^{\circ} \mathrm{C}$ ). Two types of inoculation were tested in this experiment: a control without any inoculation and inoculation with Foc Race 1 (collected from Costa Rican soils and cultivated by CORBANA's Laboratory of Biological Control). Plant inoculation was performed following protocols previously reported (García-Bastidas et al. 2014; Ordoñez et al. 2016), using root dipping for $30 \mathrm{~min}$ in a solution of $1.10^{-6}$ Foc conidia per $\mathrm{mL}$. After inoculation, plants were transferred to $2 \mathrm{~L}$ pots filled with a medium-texture and fertile ( $2.5 \%$ organic matter, $11.3 \mathrm{~g} \mathrm{~kg} \mathrm{soil}^{-1} \mathrm{Ca}, 7.05 \mathrm{~g} \mathrm{~kg} \mathrm{soil}^{-1} \mathrm{Mg}$, $0.16 \mathrm{~g} \mathrm{~kg} \mathrm{soil}^{-1} \mathrm{~K}$ and $0.01 \mathrm{~g} \mathrm{~kg} \mathrm{soil}^{-1} \mathrm{P}$ ) soil. This soil type is commonly used for growing bananas in Costa Rica and was therefore also used to test the plant response against the disease according to soil management. Treatments of the evaluated soil properties ( $\mathrm{pH}-\mathrm{N}$ ) consisted in two soil $\mathrm{pH}$ levels (lower than 5.2 and higher than 6.0) and three $\mathrm{N}$ doses (low, medium, and high). The natural soil $\mathrm{pH}$ was approximately 6.1 and it was considered the higher level of soil $\mathrm{pH}$ $\left(\mathrm{pH}_{\text {high }}\right)$. For the low $\mathrm{pH}$ level $\left(\mathrm{pH}_{\text {low }}\right)$, the $\mathrm{pH}$ was decreased to 5.1 through the application of a hydrochloric acid solution $(10 \% \mathrm{HCl})$. $\mathrm{N}$ doses were achieved through weekly differentiated $\mathrm{N}$ doses of ammonium nitrate (AN, 33.5\% N): $\mathrm{N}_{\text {low }}$ with no $\mathrm{N}$ addition relying on natural $\mathrm{N}$ in the soil; 2) $\mathrm{N}_{\text {med }}$ with $0.08 \mathrm{~N} \mathrm{~g} \mathrm{plant}^{-1}$ week $^{-1}$ supplied through $0.24 \mathrm{~g}$ of AN plant ${ }^{-1}$ week $^{-1}$; and 3) $\mathrm{N}_{\text {high }}$ with $0.25 \mathrm{~N} \mathrm{~g}$ plant $^{-1}$ week $^{-1}$ supplied through $0.75 \mathrm{~g}$ of AN plant week $^{-1}$. These $\mathrm{N}$ doses were respectively achieved through applications of $300 \mathrm{~mL}$ of solutions of AN in water with concentrations of respectively $0.00 \mathrm{~g} \mathrm{~L}^{-1} \mathrm{~N}, 0.14 \mathrm{~g} \mathrm{~L}^{-1} \mathrm{~N}$ and $0.43 \mathrm{~g} \mathrm{~L}^{-1} \mathrm{~N}$, two times week ${ }^{-1}$. Because the soil in this experiment originated from a banana plantation, also the pots not receiving any additional $\mathrm{AN}$ had a basic level of available N. Each treatment was replicated three times resulting in a total of 36 hardened tissue culture plants (approximately 3 months-old). Although the greenhouse in this experiment gave some protection, the plants were exposed to the climatic conditions of a banana growing region.

The second experiment (in The Netherlands) aim was to explore the impact of soil properties on the response of Cavendish bananas to both Fusarium wilt by Foc Race 1 and Foc TR4. The experiment was performed 
under controlled greenhouse conditions $\left(28{ }^{\circ} \mathrm{C}, 80 \%\right.$ relative humidity and $16 \mathrm{~h}$ of light) at the facilities of Plant Research International of Wageningen University and Research (WUR). It was possible to include Foc TR4 in this experiment due to the controlled and strict biosecurity conditions offered by the greenhouse facilities and because there is no risk of spreading the disease to banana plantations. Three types of inoculation were tested in this experiment: a control without any inoculation, inoculation with Foc Race 1 (Foc CNPMF 00801-R1 collected from Brazil and stored at WUR collection), and inoculation with Foc TR4 (Foc II-5 TR4 reference isolate collected from Indonesia and stored at WUR collection). The experimental setup in regarding of plant inoculation and the treatment of the selected soil properties $(\mathrm{pH}-\mathrm{N})$ was similar than in the first experiment.

Plants from this experiment were transferred to $2 \mathrm{~L}$ pots filled with a light-textured soil with intermediate fertility $\left(2.6 \%\right.$ organic matter, $0.04 \% \mathrm{~N}, 0.09 \mathrm{~g} \mathrm{~kg} \mathrm{soil}^{-1}$ $\mathrm{Ca}, 0.06 \mathrm{~g} \mathrm{~kg} \mathrm{soil}^{-1} \mathrm{Mg}, 0.03 \mathrm{~g} \mathrm{~kg}^{-1}$ soil $^{-1} \mathrm{~K}$ and $0.0013 \mathrm{~g} \mathrm{~kg} \mathrm{soil}^{-1} \mathrm{P}$ ). The same level of soil $\mathrm{pH}$ (lower than 5.2 and higher than 6.0) and the same three $\mathrm{N}$ doses $\left(0,0.08\right.$ and $0.25 \mathrm{~g} \mathrm{~N}$ plant week $\left.{ }^{-1}\right)$ were tested with four replications per each inoculation (control, Foc Race 1, and Foc TR4) resulting in an experimental design in which 72 approximately 3 months old plants were evaluated. The natural soil $\mathrm{pH}$ level was approximately 5.1 considered the lower soil $\mathrm{pH}\left(\mathrm{pH}_{\text {Low }}\right)$. For the higher $\mathrm{pH}$ level $\left(\mathrm{pH}_{\text {high }}\right.$ ), it was increased applying liming (with $\mathrm{CaCO}_{3}$ ). Inputs of $\mathrm{Ca}$ in this treatment were compensate with $\mathrm{CaCl}$ in the $\mathrm{pH}_{\text {low }} . \mathrm{N}$ doses per plant were achieved following the same experimental setup with the same $\mathrm{N}$ source (AN) as in the first experiment. Also, this soil had a basic level of available $\mathrm{N}$.

The disease expression was measured in terms of its (negative) effect on the total biomass and leaf area per plant at the harvesting moment, 54 days after inoculation (d.a.i.) in the first experiment and at 33 d.a.i. in the second experiment. Because the inoculated plants were exposed to the fungus, the presence of symptoms can be attributed to Foc. This was further confirmed as the noninoculated plants did not show symptoms. Therefore, a non-intrusive way to measure the disease according to the management of the soil properties was used to follow the development of the wilting. A disease index (DI) was calculated in each treatment of each experiment. The DI was obtained adapting the McKinney's formula (McKinney 1923) that was also used by
Haddad et al. (2018) and Rocha et al. (2020) in the same way. However, in this case, it was based on the number of sick plants and the wilted leaves: $\operatorname{DI}(\%)=$ $100 . \sum(\mathrm{f} / \mathrm{n}) \cdot(\mathrm{v} / \mathrm{x})$, where; $\mathrm{f}=$ number of sick plants; $\mathrm{n}=$ total of plants; $v=$ number of leaves with symptoms; and $\mathrm{x}=$ total number of leaves (with symptoms and healthy). The presence of the typical symptoms of the wilting of the leaves in previously inoculated plants is reported as a valid element to corroborate the presence of the disease in bananas (Dita et al. 2010; GarcíaBastidas et al. 2014 and 2020; Ordoñez et al. 2016). In addition, the dissection of wilted plants was performed to corroborate the presence of the typical internal symptoms of the disease. The data results of the experiments were independently analyzed through a factorial analysis of variance, considering in each case three factors (inoculation, soil $\mathrm{pH}$ and $\mathrm{N}$ dose) and their interactions. Differences between factors were evaluated for significance through a Tukey's range test.

\section{Results}

\section{Experiment 1}

Plant biomass and leaf area in non-inoculated plants were different $(P \leq 0.050)$ between $\mathrm{pH}_{\text {high }}$ and $\mathrm{pH}_{\text {low }}$ for all the $\mathrm{N}$ doses (Table 1). For both variables, $\mathrm{pH}_{\text {high }}$ plants had a better performance. The differences were more evident in the case of leaf biomass. Plants grown in $\mathrm{pH}_{\text {high }}$ produced around 6 times biomass than those grown in $\mathrm{pH}_{\text {low }}$. The difference followed the same behavior for the leaf area but with a less dramatic difference. In this case plants from $\mathrm{pH}_{\text {high }}$ produced around 4 times the leaf area produced in plants grown in $\mathrm{pH}_{\text {low }}$. Although, $\mathrm{N}$ soil concentrations appeared in most of the cases to be enough to fulfill the plant requirements, the lower value of the biomass was found in $\mathrm{N}_{\text {high }}$ of the $\mathrm{pH}_{\text {low }}$ group. The natural effect of the soil $\mathrm{pH}$, the $\mathrm{N}$, and their interactions in the development of the banana plant was evidenced with those results.

A higher biomass and leaf area per plant were found in plants from the control treatment for both $\mathrm{pH}_{\text {low }}$ and $\mathrm{pH}_{\text {high }}(P \leq 0.0001)$ in comparison with those which were inoculated. However, both variables were lower at $\mathrm{pH}_{\text {low }}(P \leq 0.0001)$ for both the control and the inoculated plants (Fig. 1). Even inside the inoculated group of plants the lower biomass was found in those growing in $\mathrm{pH}_{\text {low. }}$ A highly significant interaction of $\mathrm{pH} \mathrm{x}$ 
Table 1 Tukey's analysis of the comparison of biomass and leaf area at 54 days after planting from non-inoculated (control) Gros Michel banana plants (Musa AAA) grown in two soil $\mathrm{pH}$ levels (lower than 5.2 and higher than 6.0) and three $\mathrm{N}$ (with ammonium nitrate, $33.5 \% \mathrm{~N})$ doses $\left(\mathrm{N}_{\text {low }}\right.$ with no $\mathrm{N}, \mathrm{N}_{\text {med }} 0.08 \mathrm{~N}$ g plant week $^{-1}$, and $\mathrm{N}_{\text {high }} 0.25 \mathrm{~N}$ g plant week ${ }^{-1}$ ) in a greenhouse experiment (standard deviation between parentheses)

\begin{tabular}{|c|c|c|c|c|c|}
\hline \multirow[t]{2}{*}{ Variable } & \multirow[t]{2}{*}{ Soil pH } & \multicolumn{4}{|l|}{$\mathrm{N}$ dose } \\
\hline & & Low & Med & High & Average \\
\hline \multirow[t]{4}{*}{ Biomass (g plant ${ }^{-1}$ ) } & Low & 4.2 & 6.0 & 2.8 & 4.4 \\
\hline & High & 24.6 & 29.7 & 29.0 & 27.8 \\
\hline & & (15) & (17) & (19) & (12) \\
\hline & Average & 14.4 & 17.9 & 15.9 & 16.1 \\
\hline$\left(\mathrm{pH}_{\text {low }}-\mathrm{pH}_{\text {high }}\right)$ & & $-20.4 *$ & $-23.7 *$ & $-26.2 *$ & $-23.4^{*}$ \\
\hline \multirow[t]{4}{*}{ Leaf area $\left(\mathrm{cm}^{2}\right.$ plant $\left.{ }^{-1}\right)$} & Low & 57.1 & 95.4 & 62.8 & 71.7 \\
\hline & High & 210.4 & 247.8 & 316.0 & 258.0 \\
\hline & & (108) & (108) & (179) & (132) \\
\hline & Average & 133.8 & 171.6 & 189.4 & 164.9 \\
\hline$\left(\mathrm{pH}_{\text {low }}-\mathrm{pH}_{\text {high }}\right)$ & & $-153.3^{*}$ & $-152.4^{*}$ & $-126.6^{*}$ & $-186.3 *$ \\
\hline
\end{tabular}

** $\mathrm{P} \leq 0.010 ; * \mathrm{P} \leq 0.050$

inoculation was observed $(P \leq 0.0001)$. A higher plant development and growth were found in $\mathrm{pH}_{\text {high. }} \mathrm{A}$ high correlation $(r=0.95)$ between those variables (biomass and leaf area per plant) was found in these plants. The single effect of the $\mathrm{N}$ doses did not induce a significant difference on the evaluated variables. However, the soil $\mathrm{pH} \times \mathrm{N}$ interaction was almost significant $(P=0.068)$.

There were differences $(P \leq 0.0001)$ in each $\mathrm{N}$ dose for both variables when changes of obtained values were compared between the inoculated and the control groups. At the same time, the more extended gaps in this comparison (control-inoculation) were observed for $\mathrm{N}_{\text {med }}$ and $\mathrm{N}_{\text {high. }}$. The differences in $\mathrm{N}_{\text {low }}$ kept the $\mathrm{pH} \mathrm{x}$ inoculation significance, but this $\mathrm{N}$ dose had a minor difference between inoculated and control plants (Table 2).

The DI of Fusarium wilt was higher in plants from the $\mathrm{pH}_{\text {low }}(P \leq 0.050)$. For both $\mathrm{pH}_{\text {low }}$ and $\mathrm{pH}_{\text {high }}$, first symptoms were detected after the third week since planting. The $\mathrm{pH} \times \mathrm{N}$ interaction was found significant $(P \leq 0.050)$ to the DI. Besides, a higher DI was calculated in the higher $\mathrm{N}$ doses for both soil $\mathrm{pH}$ levels. This interaction $(\mathrm{pH} \times \mathrm{N})$ was linear and more accentuated in $\mathrm{pH}_{\text {low }}$ (Fig. 2). No symptoms were identified in non-inoculated plants. However, some plant from $\mathrm{pH}_{\text {low }}$ showed a chlorotic (not wilted) appearance attributed to the extreme lower $\mathrm{pH}$ in this treatment (Fig. 3).

\section{Experiment 2}

Biomass and leaf area in plants from the control (not inoculated) group are presented in Table 3. Although there were higher values in biomass and the leaf area for plants grown in $\mathrm{pH}_{\text {high }}$, only the biomass $(P \leq 0.050)$ was found different according to soil $\mathrm{pH}$. Although $\mathrm{N}_{\text {low }}$ presented a lower biomass on average, no significant differences were found for $\mathrm{N}$ doses. Inoculated and noninoculated plants grown at $\mathrm{pH}_{\text {high }}$ had significantly $(P \leq$ $0.001)$ higher biomass and leaf area than those plants grown at $\mathrm{pH}_{\text {low }}$ (Fig. 4). Soil $\mathrm{pH}$ and the inoculation interacted on the plant biomass and leaf area $(P \leq$ 0.0001). Inoculated plants at $\mathrm{pH}_{\text {low }}$ had less biomass and leaf area than those of the control. At $\mathrm{pH}_{\text {high }}$, Foc Race 1 inoculated plants equaled the biomass and surpassed the leaf area of the control. The lower soil $\mathrm{pH}$ resulted in a significant reduction of biomass and leaf area in inoculated plants. Comparing inoculation against non-inoculation, the biomass in the control exceeded the average of the inoculated groups (both Foc Race 1 and Foc TR4). Inoculated plants with Foc TR4 had consistently lower biomass and leaf area in both soil pH levels. Although the biomass and the foliar area were higher in the plants from $\mathrm{pH}_{\text {high }}$, this effect was hidden through Foc TR4 $(P=0.703)$ inoculation due to the stronger pathogenic effect of this fungus. At the end of the experiment, inoculated plants from $\mathrm{pH}_{\text {low }}$ manifested more symptoms than those from $\mathrm{pH}_{\text {high }}$ for 

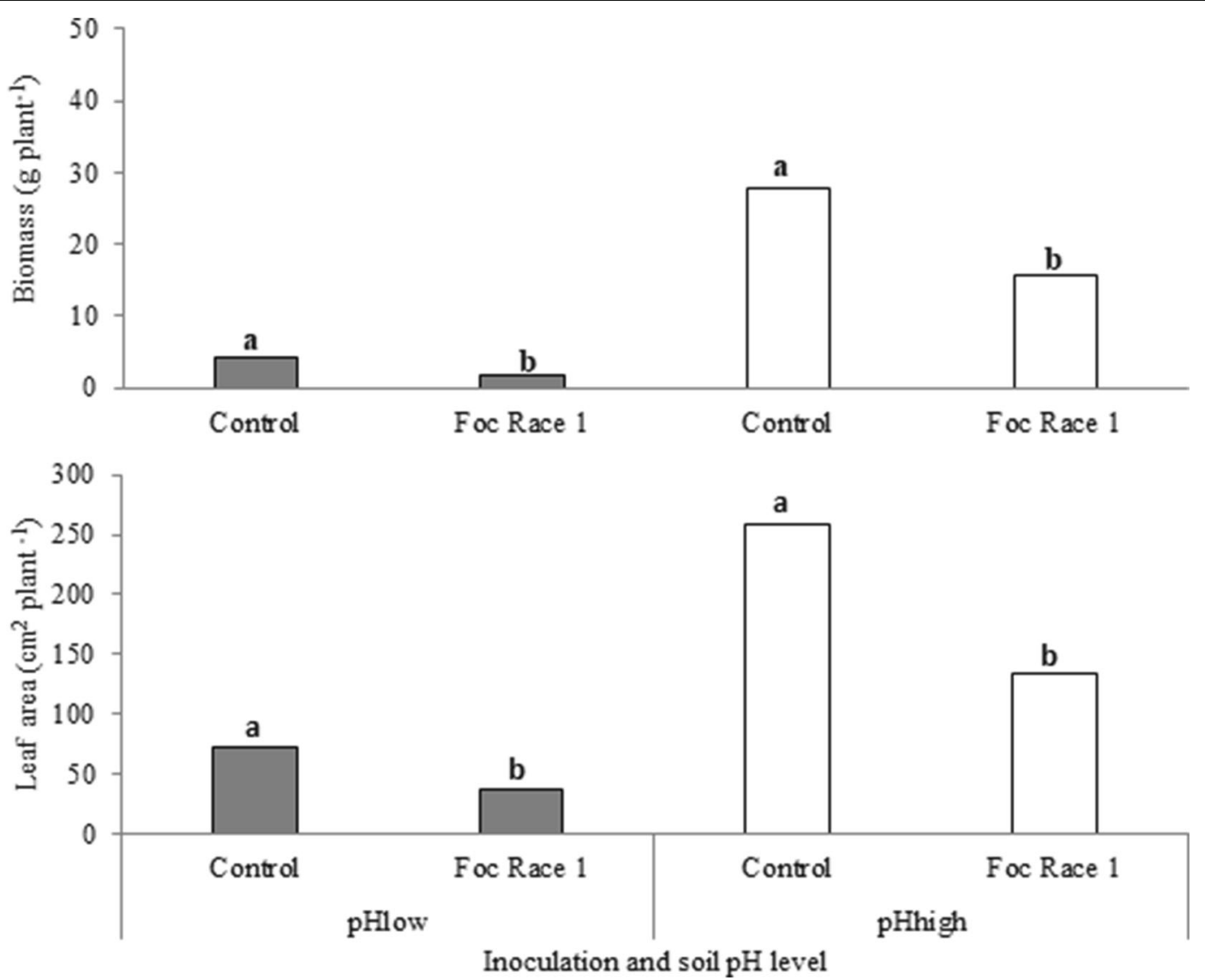

Fig. 1 Biomass and leaf area from non-inoculated (control) and inoculated Gros Michel banana plants (Musa AAA) with Fusarium oxysporum f. sp. cubense Race 1 grown in two soil $\mathrm{pH}$ levels

Table 2 Tukey's analysis of the comparison of biomass and leaf area at 54 days after inoculation between the inoculation with Fusarium oxysporum $f$. sp. cubense Race 1 against the control from Gros Michel banana plants (Musa AAA) grown in two soil $\mathrm{pH}$ levels (lower than 5.2 and higher than 6.0) and three $\mathrm{N}$ (with ammonium nitrate, $33.5 \% \mathrm{~N})$ doses $\left(\mathrm{N}_{\text {low }}\right.$ with no $\mathrm{N}, \mathrm{N}_{\text {med }}$ $0.08 \mathrm{~N}$ g plant week ${ }^{-1}$, and $\mathrm{N}_{\text {high }} 0.25 \mathrm{~N} \mathrm{~g}$ plant week $^{-1}$ ) in a greenhouse experiment in Costa Rica

\begin{tabular}{|c|c|c|c|c|c|}
\hline \multirow[t]{2}{*}{ Variable } & \multirow[t]{2}{*}{ Soil pH } & \multicolumn{4}{|l|}{ N-dose } \\
\hline & & $\mathrm{N}_{\text {low }}$ & $\mathrm{N}_{\text {med }}$ & $\mathrm{N}_{\text {high }}$ & Average \\
\hline \multirow{3}{*}{$\begin{array}{l}\text { Change in } \\
\text { biomass (g } \\
\left.\text { plant }^{-1}\right)\end{array}$} & Low & $-1.3 * *$ & $-6^{* *}$ & $-0.7 * *$ & $-2.7 * *$ \\
\hline & High & $-5.4 * *$ & $-11.2 * *$ & $-20 * *$ & $-12.2 * *$ \\
\hline & Average & -3.4 & -8.6 & -10.4 & -7.5 \\
\hline \multirow{3}{*}{$\begin{array}{l}\text { Change in leaf } \\
\text { area }\left(\mathrm{cm}^{2}\right. \\
\text { plant }\end{array}$} & Low & $-4.5 * *$ & $-95.4 * *$ & $-2.3 * *$ & $-34.1 * *$ \\
\hline & High & $-55.4 * *$ & $-96.8 * *$ & $-222 * *$ & $-87.8^{* * *}$ \\
\hline & Average & -29.9 & -96.1 & -112.2 & -60.9 \\
\hline
\end{tabular}

** $P \leq 0.010 ; * P \leq 0.050$ (lower than 5.2 and higher than 6.0) at 54 days after inoculation in a greenhouse experiment in Costa Rica. Small letters indicate differences between the treatments in each $\mathrm{pH}$ level. Segura et al.

both Foc Race 1 and Foc TR4 inoculation. All (100\%) inoculated plants for both Foc strains showed symptoms of the disease. A higher aggressive level of the symptoms was shown in $\mathrm{pH}_{\text {low }}$ with Foc TR4 inoculation. No Fusarium wilt incidence was detected in the control group.

A significant $\mathrm{pH} \times \mathrm{N}$ interaction $(P \leq 0.050)$ was found in most of the plant growth variables. Plants from the control group were compared against those from inoculated groups (Table 4). Differences between the variables of inoculated plants were lower than those from the control. The $\mathrm{N}$ dose determined the magnitude of the differences. A higher significance level $(P \leq$ 0.010) was found in $\mathrm{pH}_{\text {low }}$ for both Foc strains. Although infected plants showed lower values than the control in both $\mathrm{pH}$ levels, with $\mathrm{N}_{\text {high }}$ those differences were significant and more contrasting for the Foc Race 1 inoculated group. Differences according to $\mathrm{N}$ dose in Foc 
Fig. 2 Disease Index of Fusarium wilt by Fusarium oxysporum f. sp. cubense Race 1 at 54 days after inoculation from Gros Michel banana plants (Musa AAA) grown in two soil $\mathrm{pH}$ levels (lower than 5.2 and higher than 6.0) and three $\mathrm{N}$ (with ammonium nitrate, $33.5 \% \mathrm{~N}$ ) doses $\left(\mathrm{N}_{\text {low }}\right.$ with no $\mathrm{N}, \mathrm{N}_{\text {med }}$ $0.08 \mathrm{~N} \mathrm{~g}$ plant week $^{-1}$, and $\mathrm{N}_{\text {high }}$ $0.25 \mathrm{~N} \mathrm{~g}$ plant week $^{-1}$ ) in greenhouse experiment in Costa Rica. Segura et al.

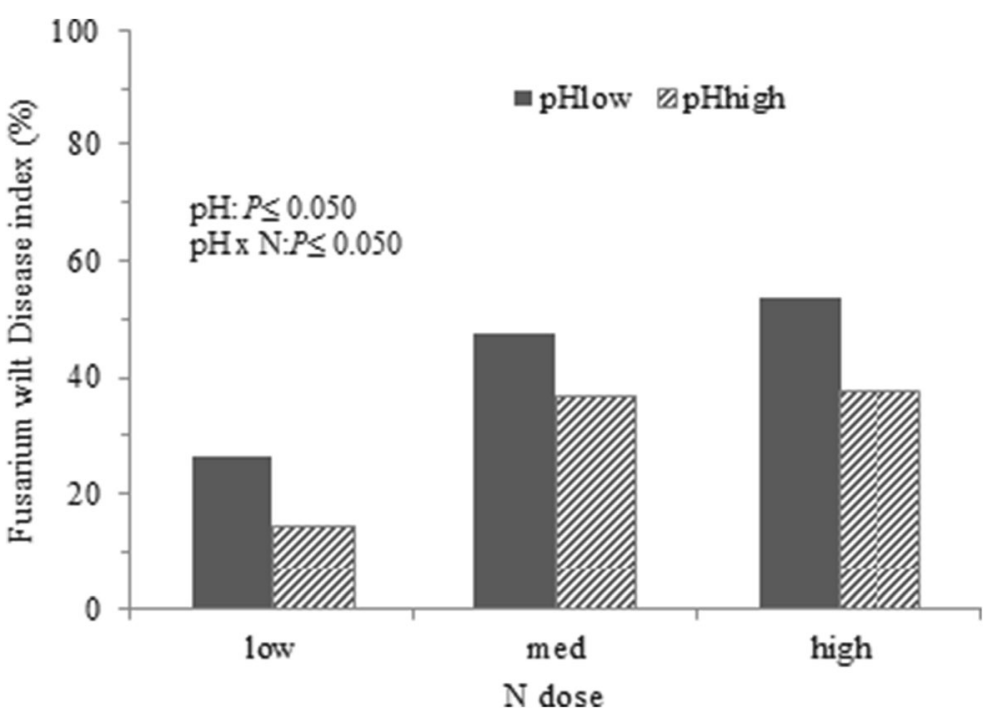

Race 1 infected plants against the control were not significant in $\mathrm{pH}_{\text {high. }}$. Foc TR4 showed stronger $(P \leq 0.005)$ differences in $\mathrm{pH}_{\text {low }}$ and $\mathrm{N}_{\text {high }}$ in almost all the variables, except for biomass. The effect of the Foc TR4 inoculation was significant in most of the cases, but less contrasting in the case of $\mathrm{pH}_{\text {high. }}$. Furthermore, the effect of the $\mathrm{N}$ doses was significant at least in one of the measured variables in both soil pH levels in Foc TR4 inoculation. Both Foc strains (Race 1 and TR4) induced symptoms in the tested banana cultivar, the Cavendish. Symptoms appeared during the first and second weeks after the inoculation and they were stronger at $\mathrm{pH}_{\mathrm{low}}$ and with Foc TR4 inoculation. Symptoms from Foc race 1 inoculation were fewer and more attenuated at the end of the experiment. However, even at the end of the experiment, plants showed symptoms for both Foc strains (Fig. 5).

The DI (Fig. 6) showed a significant effect of a $\mathrm{pH} \mathrm{x}$ $\mathrm{N}$ interaction $(P \leq 0.010)$. The wilting was more aggressive in Foc TR4 infected plants for both soil $\mathrm{pH}$ levels and all the $\mathrm{N}$ doses. DI in TR4 infected plants from $\mathrm{pH}_{\text {low }}$ reached almost $100 \%$ and around $80 \%$ in Foc Race 1. In $\mathrm{pH}_{\text {high }}$ the DI in the plants was higher for TR4 inoculation respect to the Race 1 inoculation, but it was lower than in $\mathrm{pH}_{\text {low }}$ from both inoculations.

\section{Discussion}

Although the literature shows the opportunities for the use of soil management in crop disease control, its actual implementation requires insight into the relationships between individual soil properties and crop diseases.
However, reality is complex and, in general, a combination of multiple soil properties determines crop development and disease expression. Therefore, the relationship between a soil property and a crop disease is found to be context-specific, and the response to individual soil properties, hard to establish. In addition, it is well known that crop status differs according to the multitude of soil properties. As a result, the relatively simple conceptual plant disease triangle (Huber and Haneklaus 2007) representing host, pathogen and environment interaction is actually comprised of highly complex interrelationships involving a plethora of different factors that are extremely difficult to unravel and translate in straightforward soil management recommendations. This is probably also the underlying explanation for the inconsistencies in reported results in the literature.

The complex puzzle that represents implementing soil management is constrained by the limitations of this practice. Soil properties differ in the way they can be managed. Soil texture, for instance, is reported as a property that can influence crop diseases, but it is a given and, except in some very specific cases, cannot be changed through soil management. However, it can be considered while planning new plantations. Other soil properties, for example, nutrient concentrations and soil organic matter, can be managed through mineral and organic fertilizers.

Some soil properties, such as soil $\mathrm{pH}$ and nutrient concentration, appear as attractive options to develop strategies for crop diseases control, as: i) they can be managed through e.g., fertilization and liming, and ii) 


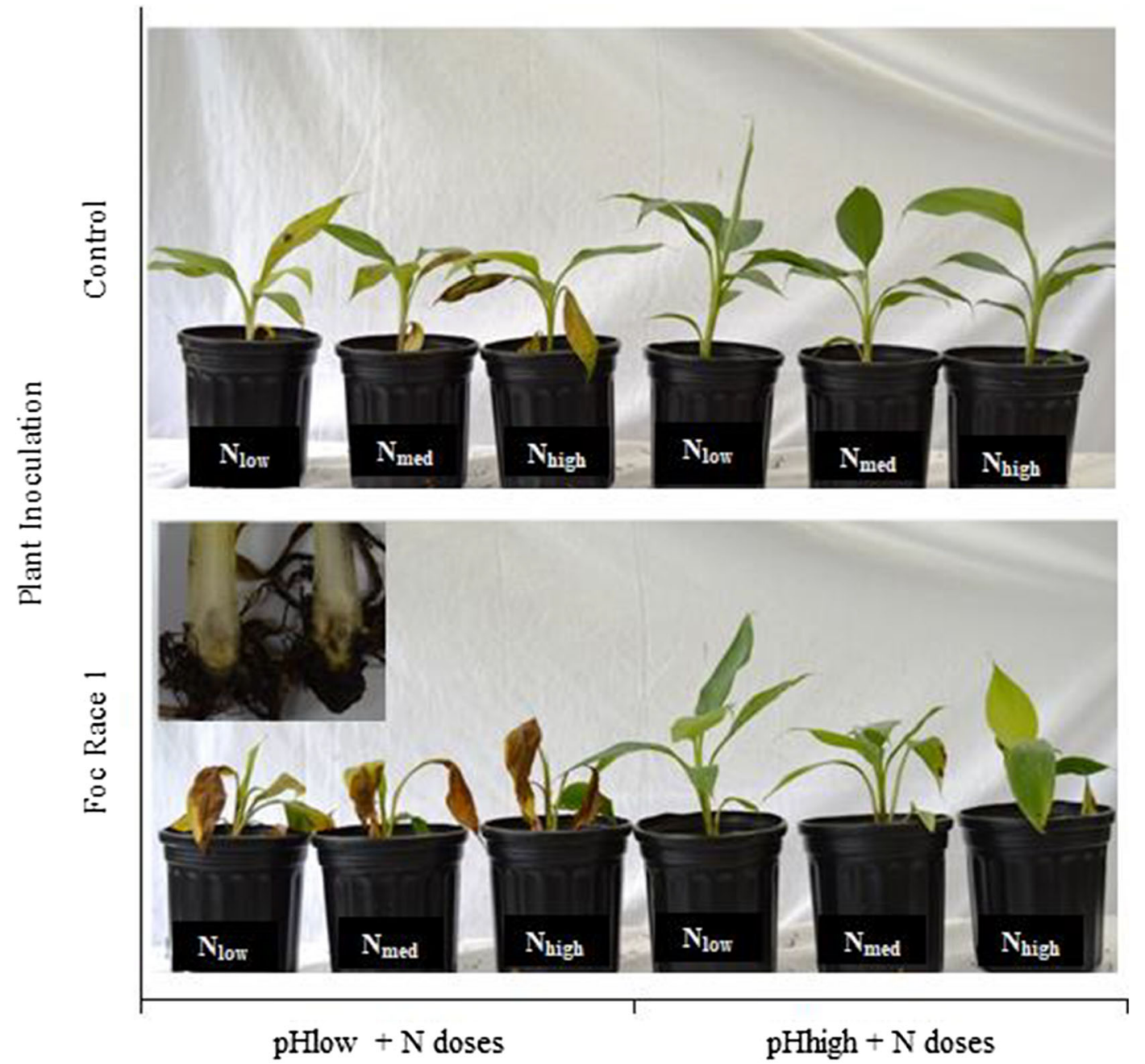

\section{Soil treatment}

Fig. 3 External and internal Fusarium wilt symptoms by Fusarium oxysporum f. sp. cubense Race 1 at 54 days after inoculation from Gros Michel banana plants (Musa AAA) grown in two soil $\mathrm{pH}$ levels (lower than 5.2 and higher than 6.0) and three

they play a role in crop diseases. However, for the development of management strategies, quantitative insight into the relation between soil properties and crop diseases is needed. This insight would allow farmers to take the economic decisions to invest in soil management. However, if the relationship is context-specific, the general validity of a relationship is limited, and it almost needs to be derived for each individual case.

Banana is an important crop with a very aggressive disease as Fusarium wilt, but with no effective conventional control options. Besides, there are not indications of soil suppressiveness against this pathogen (Deltour
$\mathrm{N}$ (with ammonium nitrate, $33.5 \% \mathrm{~N}$ ) doses $\left(\mathrm{N}_{\text {low }}\right.$ with no $\mathrm{N}, \mathrm{N}_{\text {med }}$ $0.08 \mathrm{~N} \mathrm{~g}$ plant week ${ }^{-1}$, and $\mathrm{N}_{\text {high }} 0.25 \mathrm{~N} \mathrm{~g}$ plant week $^{-1}$ ) in a greenhouse experiment in Costa Rica. Segura et al.

et al. 2017). The experiments demonstrated the role of soil $\mathrm{pH}$ and $\mathrm{N}$ and their interactions with disease incidence and severity. Soil $\mathrm{pH}$ is an important soil quality indicator in banana soils and higher crop productions generally coincide with a higher soil $\mathrm{pH}$ (Segura et al. 2015). Acidification due to heavy fertilization is indicated as a serious problem in crop management and liming is common practice (Stoorvogel and Segura 2018). In intensive production systems, banana plants are highly fertilized with up to $400 \mathrm{~kg} \mathrm{~N}$ ha year ${ }^{-1}$. Following the literature on Fusarium wilt, the intensively managed system may be highly susceptible to this 
Table 3 Tukey's analysis of the comparison of biomass and leaf area at 33 days after planting from non-inoculated (Control) Cavendish banana plants ( Musa AAA) grown in two soil $\mathrm{pH}$ levels (lower than 5.2 and higher than 6.0) and three $\mathrm{N}$ (with ammonium nitrate, $33.5 \% \mathrm{~N})$ doses $\left(\mathrm{N}_{\text {low }}\right.$ with no $\mathrm{N}, \mathrm{N}_{\text {med }} 0.08 \mathrm{~N}$ g plant week $^{-1}$, and $\mathrm{N}_{\text {high }} 0.25 \mathrm{~N} \mathrm{~g}$ plant week $^{-1}$ ) in a greenhouse experiment in the Netherlands (standard deviation between parentheses)

\begin{tabular}{|c|c|c|c|c|c|}
\hline \multirow[t]{2}{*}{ Variable } & \multirow[t]{2}{*}{ Soil pH } & \multicolumn{4}{|c|}{$\mathrm{N}$ doses } \\
\hline & & Low & Med & High & Average \\
\hline \multirow[t]{5}{*}{ Biomass (g plant ${ }^{-1}$ ) } & \multirow[t]{2}{*}{ Low } & 223 & 291 & 292 & 269 \\
\hline & & (107) & (102) & (73) & (104) \\
\hline & \multirow[t]{2}{*}{ High } & 312 & 364 & 335 & 337 \\
\hline & & $(40)$ & $(50)$ & (41) & (44) \\
\hline & \multirow[t]{2}{*}{ Average } & 268 & 328 & 313 & 303 \\
\hline$\left(\mathrm{pH}_{\text {low }}-\mathrm{pH}_{\text {high }}\right)$ & & -189 & -73 & -43 & $-68^{*}$ \\
\hline \multirow[t]{5}{*}{ Leaf area $\left(\mathrm{cm}^{2}\right.$ plant $\left.^{-1}\right)$} & \multirow[t]{2}{*}{ Low } & 1423 & 1259 & 1574 & 1419 \\
\hline & & $(962)$ & (412) & $(287)$ & $(554)$ \\
\hline & \multirow[t]{2}{*}{ High } & 1524 & 1878 & 1460 & 1621 \\
\hline & & $(321)$ & (118) & (449) & (296) \\
\hline & \multirow[t]{2}{*}{ Average } & 1473 & 1569 & 1517 & 1520 \\
\hline$\left(\mathrm{pH}_{\text {low }}-\mathrm{pH}_{\text {high }}\right)$ & & -101 & -619 & 114 & -202 \\
\hline
\end{tabular}

**P $\leq 0.010 ; * P \leq 0.050$

disease due to the acidification and $\mathrm{N}$ fertilization. General recommendations based on current literature would include liming and possibly a reduction in $\mathrm{N}$ fertilization.

The difference in the duration of the experiments was due to the rapid development of the plants in the second experiment under the optimal and controlled conditions relative to the more natural conditions in the first experiment. However, for both experiments, the effect of soil $\mathrm{pH}$ and the interaction of soil $\mathrm{pH}$ and $\mathrm{N}$ on the disease expressed as the biomass, the leaf area and the DI evaluated how the predisposition of Gros Michel banana to Foc Race 1 (and TR4) can be modulated. The effect of those soil properties was also reported in field experiences (Rishbeth 1955; Stover 1961). This effect of those soil properties could have played a role in the devastation of Gros Michel by Foc Race 1 in Latin America during the last century. The decimation of the former main banana subgroup (the Gros Michel) appears expectable with the incipient knowledge about the fungus and its dissemination (Dita et al. 2018) and the recently reported interactions of Foc with e.g., soil nematodes (Rocha et al. 2020) and the banana weevil
(Guillén et al. 2021). Due the lack of awareness about the importance of tested soil properties in the expression of the disease, the standard management of the crop with the common application of high rates of $\mathrm{N}$ (and the consequent drop of $\mathrm{pH}$ ) could increase the severity of the disease. In the case of this research, the effect of the $\mathrm{N}$ doses in dropping soil $\mathrm{pH}$ was almost absent due the implemented procedure of $\mathrm{N}$ application in a solution.

The potential of soil management in Fusarium wilt incidence was clear when the Cavendish cultivar showed symptoms caused by Foc Race 1 in the second experiment. Although those cultivars are widely accepted as resistant to Foc Race 1(Harper 1950; PerezVicente 2004; Ploetz 1990), the extreme stress in $\mathrm{pH}_{\text {low }}$ induced a higher predisposition to the disease. It is reported that Cavendish can be affected by Foc Race 1 in young stages under stress conditions, such as extreme soil temperatures and high inoculum level (Brake et al. 1995; Smith et al. 2008). Besides, a lower $\mathrm{pH}$ can be considered as an extreme condition with potential to accelerate the disease incidence in young Cavendish plants, as was found in the second experiment.

The differences in biomass and leaf area between $\mathrm{pH}$ levels in the control plants for both experiments can be attributed to the effect of soil $\mathrm{pH}$ on the plant nutritional intake. At the same time, this condition could more highly predispose the plant to Fusarium wilt because of the lack of nutrients. Besides, the additional effect of the lower $\mathrm{pH}$ is a higher solubilization of aluminum (Al). A higher $\mathrm{Al}$ concentration is reported to negatively affect banana production (Segura et al. 2015). Nutrients may be required to grow and to activate the plant responses against the fungus. Under the extreme soil condition of $\mathrm{pH}_{\text {low }}$, even a Foc Race 1- resistant plant as the Cavendish, can be affected by the diseases. In $\mathrm{pH}_{\text {high }}$, the plant can take up more nutrients and water from the soil (Neumann and Römheld 2012) which increased the biomass production.

The experiments showed that previous reports on Fusarium wilt and Gros Michel banana can be replicated. It was shown that soil properties can modulate disease incidence by Foc TR4 in Cavendish. Besides, it seems like the response of Gros Michel to the disease according to soil $\mathrm{pH}$ differences is more contrasting than the Cavendish cultivar. The experiments showed a slightly higher predisposition of Gros Michel to Foc Race 1 than Cavendish to Foc TR4 to the management of this soil property. This could suggest that the impact of Foc TR4 on Cavendish would be less severe than the 

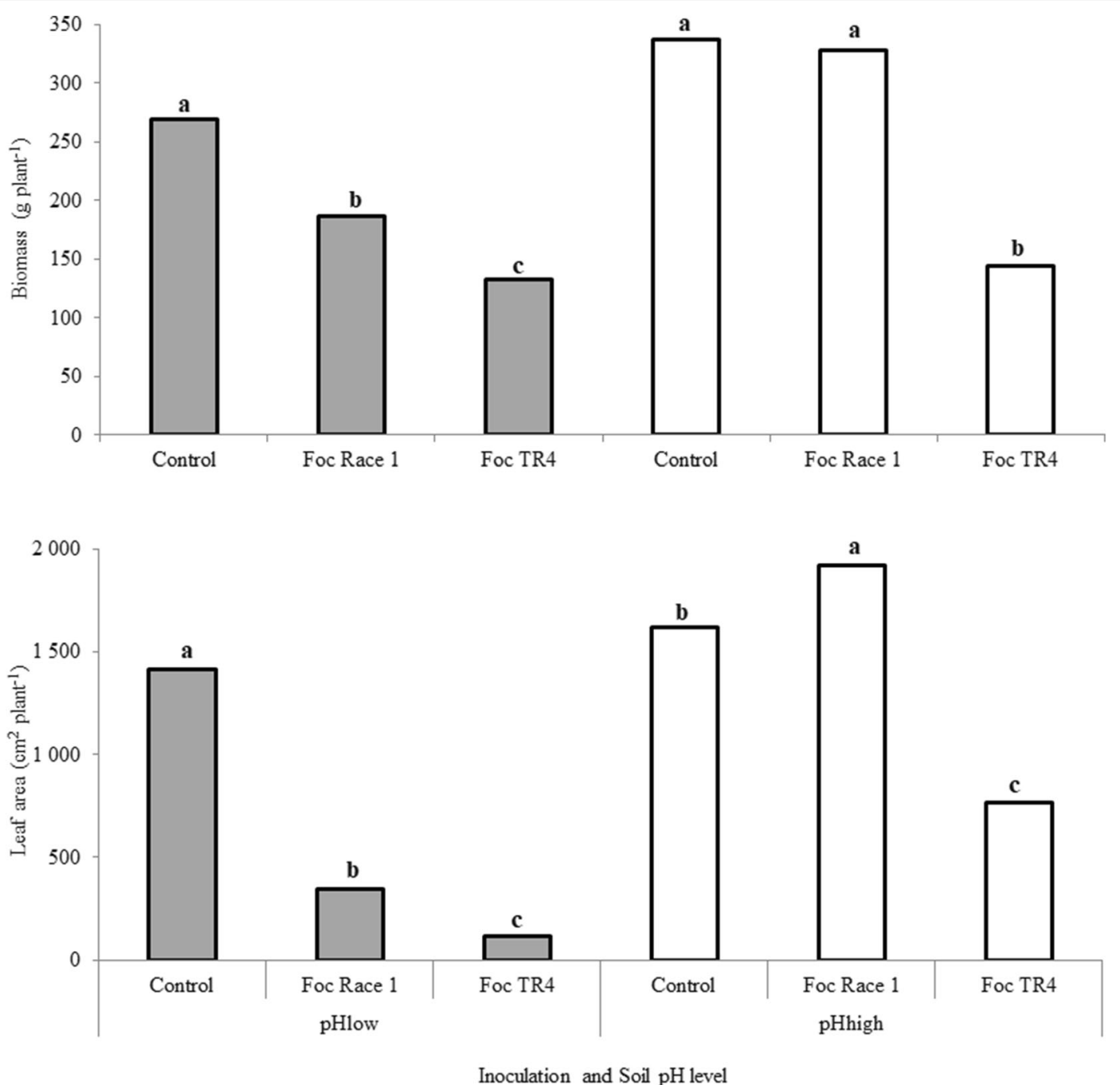

Fig. 4 Biomass and leaf area at 33 days after inoculation from non inoculated (Control) and inoculated Cavendish banana plants (Musa AAA) with Fusarium oxysporum f. sp. cubense (Race 1 and TR4) grown in two soil $\mathrm{pH}$ levels (lower than 5.2 and higher

impact of Foc race 1 on Gros Michel. However, this comparison is difficult, as conditions differ between greenhouse and the field, and because crop management has been intensified over the years.

Both experiments showed the potential of soil management as a component for an integrated control of Fusarium wilt in bananas. The effect of managing soil properties on Foc Race 1 in the Gros Michel subgroup was confirmed. In addition, soil management appears to have similar effects on Foc TR4. The results indicate the importance of the selected soil properties $(\mathrm{pH}$ and $\mathrm{N}$ ) and their role in the predisposition of banana to the disease. The concept of soil management strategy in than 6.0) in a greenhouse experiment in the Netherlands. Small letters indicate differences between the treatments in each $\mathrm{pH}$ level. Segura et al.

crop disease management requires more detailed studies, but the results support investing in this alternative approach to crop disease management in present and future crop production. This is particularly applicable for Fusarium wilt in banana, where this kind of studies is highly needed due to the direct threat of Foc TR4.

\section{Conclusions}

Crop production is constantly threatened by diseases. There are an important number of diseases for each crop and new diseases are also common in crop production. 
Table 4 Tukey's analysis of the comparison of biomass and leaf area at 33 days after inoculation between Fusarium oxysporum $f$. sp. cubense, (Race 1 and TR4) inoculation against not inoculation (Control) in Cavendish banana plants (Musa AAA) grown in two soil pH levels (lower than 5.2 and higher than 6.0) and three $\mathrm{N}$ (with ammonium nitrate, $33.5 \% \mathrm{~N})$ doses $\left(\mathrm{N}_{\text {low }}\right.$ with no $\mathrm{N}, \mathrm{N}_{\text {med }}$ $0.08 \mathrm{~N} \mathrm{~g}$ plant week ${ }^{-1}$, and $\mathrm{N}_{\text {high }} 0.25 \mathrm{~N} \mathrm{~g}$ plant week $^{-1}$ ) in a greenhouse experiment in the Netherlands

\begin{tabular}{|c|c|c|c|c|c|c|c|c|c|}
\hline \multirow[t]{2}{*}{ Variable } & \multirow{2}{*}{$\begin{array}{l}\text { Soil } \\
\mathrm{pH}\end{array}$} & \multicolumn{4}{|c|}{ Foc Race 1 - Control } & \multicolumn{4}{|c|}{ Foc TR4 - Control } \\
\hline & & $\mathrm{N}_{\text {low }}$ & $\mathrm{N}_{\text {med }}$ & $\mathrm{N}_{\text {high }}$ & Average & $\mathrm{N}_{\text {low }}$ & $\mathrm{N}_{\text {med }}$ & $\mathrm{N}_{\text {high }}$ & Average \\
\hline \multirow[t]{3}{*}{ Change in biomass (g plant ${ }^{-1}$ ) } & Low & -34 & -10 & -32 & $-82 *$ & -121 & -124 & -164 & $-136^{*}$ \\
\hline & High & 33 & -31 & -29 & 9 & -161 & $-187 *$ & $-232 *$ & $-193 *$ \\
\hline & Average & -1 & 21 & -31 & 24 & -141 & -156 & -198 & -165 \\
\hline \multirow[t]{3}{*}{ Change in leaf area $\left(\mathrm{cm}^{2}\right.$ plant $\left.{ }^{-1}\right)$} & Low & $-1008^{*}$ & $-923^{*}$ & $-1293 * *$ & $-1075^{* *}$ & $-1345^{* *}$ & $-1142 * *$ & $-1426 * *$ & $-1304 * *$ \\
\hline & High & 414 & 72 & 415 & 300 & -797 & -755 & $-1018^{*}$ & $-857 * *$ \\
\hline & Average & -297 & -426 & -439 & -388 & -1071 & -949 & -1222 & -1081 \\
\hline
\end{tabular}

** $P \leq 0.01 ; * P \leq 0.050$

The role of soil properties in crop disease expression differs according to the disease and the soil property. The case of $\mathrm{pH}$ and $\mathrm{N}$ in Fusarium wilt in banana illustrates the opportunity for soil management to deal with this disease. The relationship of these soil properties in the incidence of the disease by Foc Race 1 in Gros Michel subgroup was confirmed. Besides, it was demonstrated that Cavendish and TR4, the current major threat in banana production, followed similar trends than those found for Gros Michel and Foc Race 1. Since the Cavendish is largely resistant to Foc Race 1, the induced expression of symptoms shows the potential of soil properties in the plant predisposition to the disease. Based on these results and given the current impact of Foc TR4 in banana production, continuing the studies in this discipline appears to be attractive and necessary. Although practices of soil management as liming to increase soil $\mathrm{pH}$ and balanced use of $\mathrm{N}$ sources (e.g.

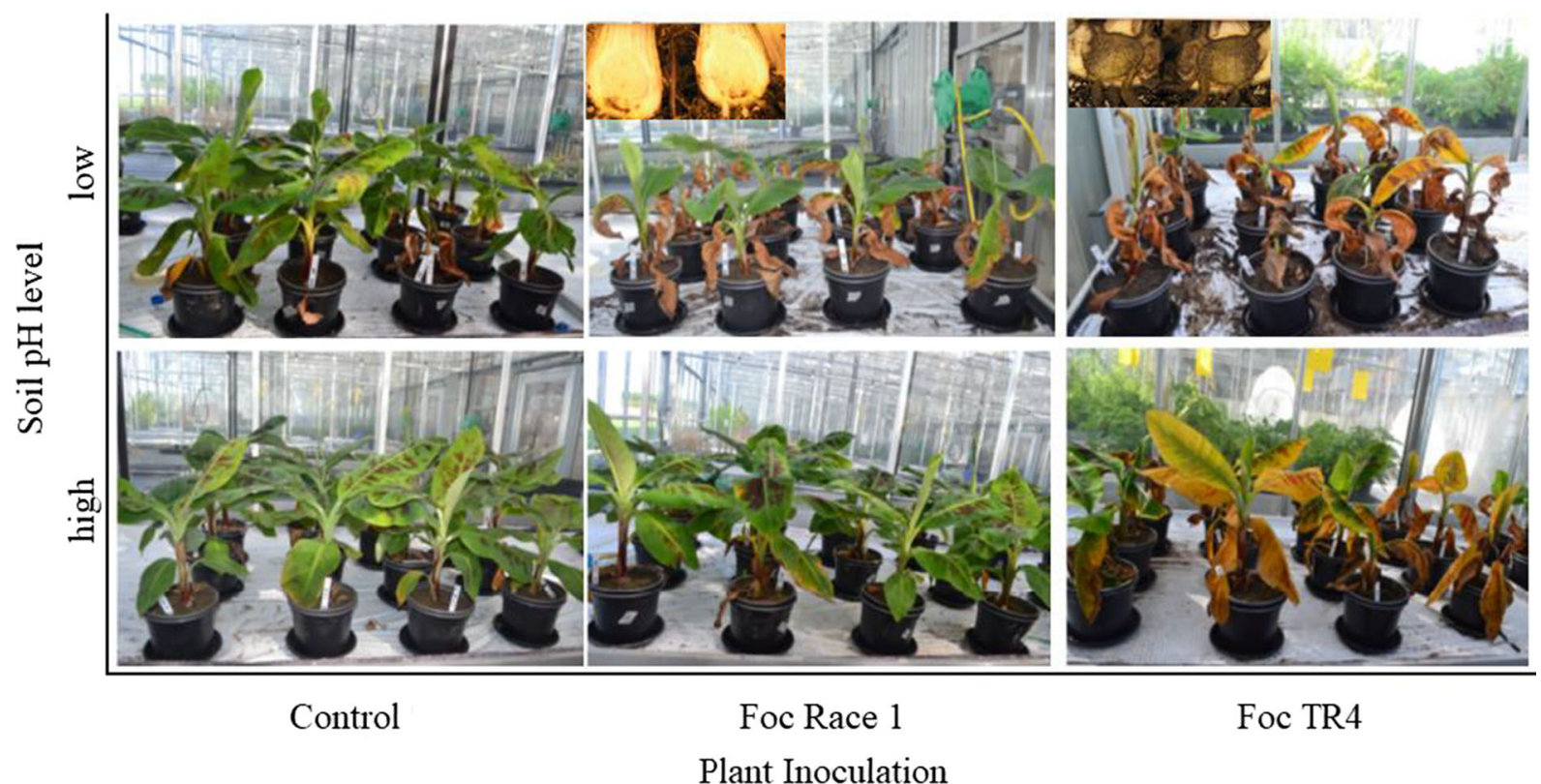

Fig. 5 External and internal Fusarium wilt symptoms by Fusarium oxysporum f. sp. cubense (Race 1 and TR4) at 33 days after inoculation from Cavendish banana plants (Musa AAA) grown in two soil $\mathrm{pH}$ levels (lower than 5.2 and higher than 6.0) in a greenhouse experiment in the Netherlands. Segura et al. 
Fig. 6 Disease index of Fusarium wilt by Fusarium oxysporum $\mathrm{f}$. sp. cubense (Race 1 and TR4) at 33 days after inoculation from Cavendish banana plants (Musa AAA) grown in two soil $\mathrm{pH}$ levels (lower than 5.2 and higher than 6.0) and three $\mathrm{N}$ (with ammonium nitrate, $33.5 \% \mathrm{~N}$ ) doses $\left(\mathrm{N}_{\text {low }}\right.$ with no $\mathrm{N}, \mathrm{N}_{\text {med }}$ $0.08 \mathrm{~N} \mathrm{~g}_{\text {plant week }}^{-1}$, and $\mathrm{N}_{\text {high }}$ $0.25 \mathrm{~N} \mathrm{~g}$ plant week $^{-1}$ ) in a greenhouse experiment in the Netherlands. Segura et al.

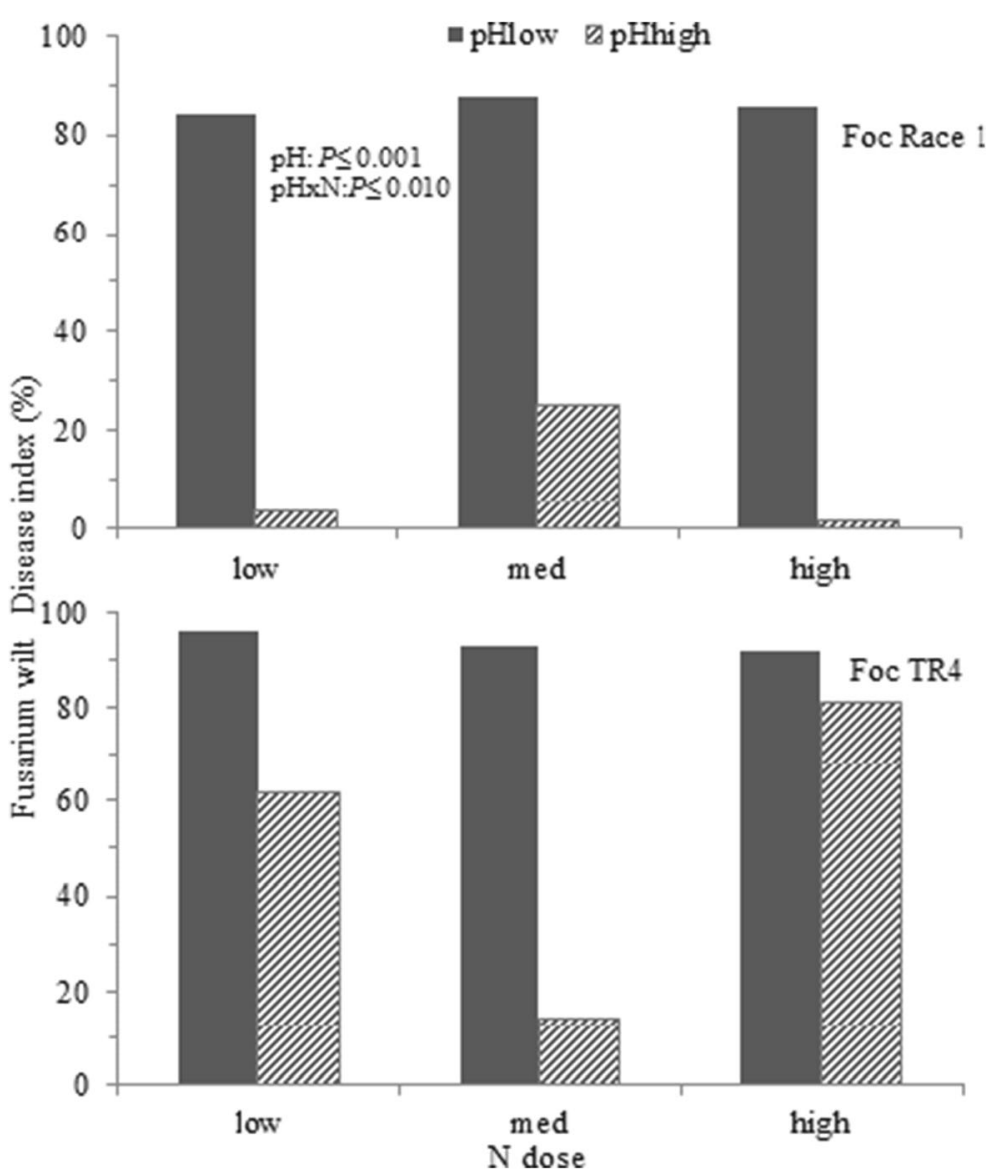

ammonium nitrate as in this case) can be considered as preventing measures to reduce Fusarium wilt in the banana crop, the results need to be confirmed in experiments under field and/or farm conditions.

Acknowledgments Susan Klinkert MSc. and Raphael Hürliman MSc. are acknowledged for supporting soil characterization and sampling in the Costa Rican experiment. Fabio Blanco MSc. is gratefully acknowledged for the support with the statistical analysis. The study is financially supported by CORBANA and the Interdisciplinary Research and Education Fund (INREF) of Wageningen University.

Author's contribution All the authors took part in conceptualization of the research and editing the manuscript and consent its publication. RS, JJS and JAS performed the greenhouse experiment in Costa Rica. RS, MS, FG, JJS and GK performed the greenhouse experiment in the Netherlands. RS, JJS and JAS wrote the manuscript which was edited by all authors to obtain the final version.

\section{Declarations}

Ethical statement The manuscript is not submitted to another journal. The submitted manuscript is original and it is not published elsewhere in any form or language (partially or in full), and it does not concern an expansion of previous work. The study is not split up into several parts to increase the quantity of submissions and submitted to various journals or to one journal over time. Results are presented clearly, honestly, and without fabrication, falsification, or inappropriate data manipulation. Data was collected from greenhouse experiments and managed with statistical software with total honestly and transparence. No data, text, or theories by others are presented as if they were the author's own. All collected data, and the performed analysis are available. Proper acknowledgements to other works are given. This piece of work respects third parties' rights such as copyright and/or moral rights.

Open Access This article is licensed under a Creative Commons Attribution 4.0 International License, which permits use, sharing, adaptation, distribution and reproduction in any medium or format, as long as you give appropriate credit to the original author(s) and 
the source, provide a link to the Creative Commons licence, and indicate if changes were made. The images or other third party material in this article are included in the article's Creative Commons licence, unless indicated otherwise in a credit line to the material. If material is not included in the article's Creative Commons licence and your intended use is not permitted by statutory regulation or exceeds the permitted use, you will need to obtain permission directly from the copyright holder. To view a copy of this licence, visit http://creativecommons.org/licenses/by/4.0/.

\section{References}

Amir, H., \& Alabouvette, C. (1993). Involvement of soil abiotic factors in the mechanisms of soil suppressiveness to Fusarium wilts. Soil Biology and Biochemistry, 25(2), 157164.

Atim, M., Beed, F., Tusiime, G., Tripathi, L., \& van Asten, P. (2013). High potassium, calcium, and nitrogen application reduce susceptibility to Banana Xanthomonas wilt caused by Xanthomonas campestris pv. musacearum. Plant Disease, 97(1), 123-130. https://doi.org/10.1094/PDIS-07-12-0646RE.

Aurore, G., Parfait, B., \& Fahrasmane, L. (2009). Bananas, raw materials for making processed food products. Trends in Food Science \& Technology, 20(2), 78-91. https://doi. org/10.1016/j.tifs.2008.10.003.

Bowen, A., Orr, R., McBeath, A. V., Pattison, A., \& Nelson, P. N. (2019). Suppressiveness or conduciveness to Fusarium wilt of bananas differs between key Australian soils. Soil Research, 57(2), 158. https://doi.org/10.1071/SR18159.

Brake, V. M., Pegg, K. G., Irwin, J. A. G., \& Chaseling, J. (1995). The influence of temperature, inoculum level and race of Fusarium oxysporum f. sp. cubense on the disease reaction of banana cv. Cavendish. Crop and Pasture Science, 46(3), 673-685.

Brennan, R. F. (1992). The role of manganese and nitrogen nutrition in the susceptibility of wheat plants to take-all in Western Australia. Fertilizer research, 31(1), 35-41.

Butler, D. (2013). Fungus threatens top banana. Nature, 504(7479), 195-196. https://doi.org/10.1038/504195a.

Dale, J., Paul, J.-Y., Dugdale, B., \& Harding, R. (2017). Modifying bananas: From Transgenics to organics? Sustainability, 9(3), 333-346. https://doi.org/10.3390 /su9030333.

Deltour, P., C. França, S., Liparini Pereira, O., Cardoso, I., De Neve, S., Debode, J., \& Höfte, M. (2017). Disease suppressiveness to Fusarium wilt of banana in an agroforestry system: Influence of soil characteristics and plant community. Agriculture, Ecosystems \& Environment, 239, 173-181. https://doi.org/10.1016/j.agee.2017.01.0182017.01.018.

Dita, M. A., Garming, H., Van den Bergh, I., Staver, C., \& Lescot, T. (2013). Banana in Latin America and the Caribbean: Current state, challenges and perspectives. Acta Horticulturae, (986), 365-380. https://doi.org/10.17660 /ActaHortic.2013.986.39.

Dita, M. A., Waalwijk, C., Buddenhagen, I. W., Souza Jr., M. T., \& Kema, G. H. J. (2010). A molecular diagnostic for tropical race 4 of the banana fusarium wilt pathogen. Plant
Pathology, 59(2), 348-357. https://doi.org/10.1111/j.13653059.2009.02221.x.

Dita, M., Barquero, M., Heck, D., Mizubuti, E. S. G., \& Staver, C. P. (2018). Fusarium wilt of Banana: Current knowledge on epidemiology and research needs toward sustainable disease management. Frontiers in Plant Science, 9, 1468. https://doi. org/10.3389/fpls.2018.01468.

Domínguez, J., Negrín, M. A., \& Rodríguez, C. M. (2008). Soil potassium indices and clay-sized particles affecting Bananawilt expression caused by soil fungus in Banana plantation development on transported volcanic soils. Communications in Soil Science and Plant Analysis, 39(3-4), 397-412. https://doi.org/10.1080/00103620701826522.

Domínguez, J., Negrín, M. A., \& Rodríguez, C. M. (2001). Aggregate water-stability, particle-size and soil solution properties in conducive and suppressive soils to Fusarium wilt of banana from Canary Islands (Spain). Soil Biology and Biochemistry, 33(4-5), 449-455. https://doi.org/10.1016 /S0038-0717(00)00184-X.

Doran, J. W., \& Zeiss, M. R. (2000). Soil health and sustainability: Managing the biotic component of soil quality. Applied Soil Ecology, 15(1), 3-11. https://doi.org/10.1016/S0929-1393 (00)00067-6.

Dordas, C. (2008). Role of nutrients in controlling plant diseases in sustainable agriculture. A review. Agronomy for Sustainable Development, 28(1), 33-46. https://doi.org/10.1051 /agro:2007051.

Duffy, B. K., Ownley, B. H., \& Weller, D. M. (1997). Soil chemical and physical properties associated with suppression of take-all of wheat by Trichoderma koningii. Phytopathology, 87(11), 1118-1124.

Fernandez-Falcon, M., Fox, R. L., \& Trujillo, E. E. (1984). Interactions of soil $\mathrm{pH}$, nutrients and moisture on phytophthora root rot of avocado. Plant and Soil, 81(2), 165-176. https://doi.org/10.1007/BF02197148.

García-Bastidas, F. A., Ordóñez, N., Konkol, J., Al-Qasim, M., Naser, Z., Abdelwali, M., et al. (2014). First report of Fusarium oxysporum $\mathrm{f}$. sp. cubense tropical race 4 associated with Panama disease of Banana outside Southeast Asia. Plant Disease, 98(5), 694-694. https://doi.org/10.1094/PDIS-0913-0954-PDN.

García-Bastidas, F. A., Quintero-Vargas, J. C., Ayala-Vasquez, M., Schermer, T., Seidl, M. F., Santos-Paiva, M., Noguera, A. M., Aguilera-Galvez, C., Wittenberg, A., Hofstede, R., Sørensen, A., \& Kema, G. H. J. (2020). First report of Fusarium wilt tropical race 4 in Cavendish bananas caused by Fusarium odoratissimum in Colombia. Plant Disease, 104(3), 994-994. https://doi.org/10.1094/PDIS-09-19-1922PDN.

Geense, P., Pattison, A. B., Kukulies, T. L., Scholberg, J. M. S., \& Molina, A. B. (2015). Can changes in soil properties in organic Banana production suppress Fusarium wilt? Natural Resources, 06(03), 181-195. https://doi. org/10.4236/nr.2015.63017.

Ghorbani, R., Wilcockson, S., Koocheki, A., \& Leifert, C. (2008). Soil management for sustainable crop disease control: A review. Environmental Chemistry Letters, 6(3), 149-162. https://doi.org/10.1007/s10311-008-0147-0. 
Goto, K. (1985). Relationships between soil pH, available calcium and prevalence of potato scab. Soil Science and Plant Nutrition, 31(3), 411-418. https://doi.org/10.1080 /00380768.1985.10557448.

Guillén, C., Tixier, P., Tapia Fernández, A., Conejo Barboza, A. M., Sandoval Fernández, J. A., \& Lapeyre de Bellaire, L. (2021). Can the banana weevil Cosmopolites sordidus be a vector of Fusarium oxysporum f.sp. cubense race 1? Unravelling the internal and external acquisition of effective inoculum. Pest Management Science, 6339. https://doi. org/10.1002/ps.6339.

Haddad, F., Rocha, L. S., Soares, A. C. F., Martins, I. P. S., Teixeira, L. A. J., Staver, C., \& Dita, M. (2018). Management of Fusarium wilt of bananas in Minas Gerais, Brazil. Acta Horticulturae, (1196), 137-146. https://doi. org/10.17660/ActaHortic.2018.1196.16.

Harper, J. L. (1950). Studies in the resistance of certain varieties of banana to Panama disease. Plant and Soil, 2(4), 383-394. https://doi.org/10.1007/BF01343358.

Harrison, U. J., \& Shew, H. D. (2001). Effects of soil pH and nitrogen fertility on the population dynamics of Thielaviopsis basicola. Plant and Soil, 228(2), 147-155.

Hoffland, E., Jeger, M. J., \& van Beusichem, M. L. (2000). Effect of nitrogen supply rate on disease resistance in tomato depends on the pathogen. Plant and Soil, 218(1-2), 239-247.

Hoffland, E., van Beusichem, M. L., \& Jeger, M. J. (1999). Nitrogen availability and susceptibility of tomato leaves to Botrytis cinerea. Plant and Soil, 210, 263-272. https://doi. org/10.1023/A:1004661913224.

Höper, H., Steinberg, C., \& Alabouvette, C. (1995). Involvement of clay type and $\mathrm{pH}$ in the mechanisms of soil suppressiveness to fusarium wilt of flax. Soil Biology and Biochemistry, 27(7), 955-967. https://doi.org/10.1016/0038-0717(94 )00238-V.

Huber, D. M., \& Haneklaus, S. (2007). Managing nutrition to control plant disease. Landbauforsch Volkenrode, 57(4), 313-322.

Huber, D. M., \& Watson, R. (1974). Nitrogen form and plant disease. Annual Review of Phytopathology, 12, 139-165.

Huber, D., Römheld, V., \& Weinmann, M. (2012). Relationship between nutrition, plant diseases and pests. In Marschner's Mineral Nutrition of Higher Plants (pp. 283-298). Elsevier. https://doi.org/10.1016/B978-0-12-384905-2.00010-8.

Hwang, S.-C., \& Ko, W.-H. (2004). Cavendish Banana cultivars resistant to Fusarium wilt acquired through Somaclonal variation in Taiwan. Plant Disease, 88(6), 580-588. https://doi. org/10.1094/PDIS.2004.88.6.580.

Janvier, C., Villeneuve, F., Alabouvette, C., Edel-Hermann, V., Mateille, T., \& Steinberg, C. (2007). Soil health through soil disease suppression: Which strategy from descriptors to indicators? Soil Biology and Biochemistry, 39(1), 1-23. https://doi.org/10.1016/j.soilbio.2006.07.001.

Lacey, M. J., \& Wilson, C. R. (2001). Relationship of common scab incidence of potatoes grown in Tasmanian ferrosol soils with $\mathrm{pH}$, exchangeable cations and other chemical properties of those soils. Jorunal of Phytopatology, 149, 679-683.

Lambert, D. H., Powelson, M. L., \& Stevenson, W. R. (2005). Nutritional interactions influencing diseases of potato. American Journal of Potato Research, 82(4), 309-319. https://doi.org/10.1007/BF02871961.
Leitch, M. H., \& Jenkins, P. D. (1995). Influence of nitrogen on the development of Septoria epidemics in winter wheat. The Journal of Agricultural Science, 124(03), 361-368. https://doi.org/10.1017/S0021859600073329.

McKinney, R. H. (1923). Influence of soil temperature and moisture on infection of wheat seedlings by Helminthosporium sativum. Journal of Agriculture Research, 6, 195-218.

Miller, J. S., \& Rosen, C. J. (2005). Interactive effects of fungicide programs and nitrogen management on potato yield and quality. American Journal of Potato Research, 82(5), 399409. https://doi.org/10.1007/BF02871970.

Molina, A. B., Fabregar, E. G., Sinohin, V., Fourie, G., \& Viljoen, A. (2008). Tropical race 4 of Fusarium oxysporum f.sp. cubense causing new Panama wilt epidemics in Cavendish varieties in the Philippines. Phytopathology, 98, S 108.

Neumann, G., \& Römheld, V. (2012). Rhizosphere chemistry in relation to plant nutrition. In Marschner's Mineral Nutrition of Higher Plants (pp. 347-368). Elsevier. https://doi. org/10.1016/B978-0-12-384905-2.00014-5.

Olesen, J. E., JøRgensen, L. N., Petersen, J., \& Mortensen, J. V. (2003). Effects of rate and timing of nitrogen fertilizer on disease control by fungicides in winter wheat. 1. Grain yield and foliar disease control. Journal of Agricultural Science, 140(1), 1-13. https://doi.org/10.1017/S0021859602002885.

Ordoñez, N., García-Bastidas, F., Laghari, H. B., Akkary, M. Y., Harfouche, E. N., al Awar, B. N., \& Kema, G. H. J. (2016). First Report of Fusarium oxysporum f. sp. cubense Tropical Race 4 Causing Panama Disease in Cavendish Bananas in Pakistan and Lebanon. Plant Disease, 100(1), 209. https://doi.org/10.1094/PDIS-12-14-1356-PDN.

Ordoñez, N., Seidl, M. F., Waalwijk, C., Drenth, A., Kilian, A., Thomma, B. P. H. J., et al. (2015). Worse comes to worst: Bananas and Panama disease-When plant and pathogen clones meet. PLoS Pathogens, 11(11), e1005197. https://doi.org/10.1371/journal.ppat.1005197.

Orr, R., \& Nelson, P. N. (2018). Impacts of soil abiotic attributes on Fusarium wilt, focusing on bananas. Applied Soil Ecology, 132, 20-33. https://doi.org/10.1016/j.apsoil.2018.06.019.

Oyarzun, P. J., Gerlagh, M., \& Zadoks, J. C. (1998). Factors associated with soil receptivity to some fungal root rot pathogens of peas. Applied Soil Ecology, 10(1-2), 151-169. https://doi.org/10.1016/S0929-1393(98)00042-0.

Perez-Vicente, L. (2004). Fusarium wilt (Panama disease) of bananas: An updating review of the current knowledge on the disease and its causal agent. Fitosanidad, 8, 27-38.

Persson, L., \& Olsson, S. (2000). Abiotic characteristics of soils suppressive to Aphanomyces root rot. Soil Biology and Biochemistry, 32(8), 1141-1150.

Ploetz, R. C. (1990). Vegetative compatibility in Fusarium Oxysporum f.sp.cubense: Classifying previosly noncharacterized strains. Acta Horticulturae, (275), 699706.

Ploetz, R. C. (2015). Management of Fusarium wilt of banana: A review with special reference to tropical race 4. Crop Protection, 73, 7-15. https://doi.org/10.1016/j. cropro.2015.01.007.

Pocasangre, L. E., Perez-Vicente, L., \& Ferris, H. (2017). Organic Banana disease management. In Plant Diseases and Their Management in Organic Agriculture (pp. 354-365). The American Phytopathological society. https://doi.org/10.1094 19780890544785. 
Rengel, Z. (2000). Mineral nutrition of crops: fundamental mechanisms and implications (Vol. 37). https://doi.org/10.5860 /CHOICE.37-5661. Accessed 22 July 2013.

Rishbeth, J. (1955). Fusarium wilt of bananas in Jamaica. II. Some aspects of host-parasite relationships. Annals of Botany, N.S., XXI(82), 215-245.

de Rocha, A. J., dos Ferreira, M. S., de Rocha, L. S., Oliveira, S. A. S., Amorim, E. P., Mizubuti, E. S. G., \& Haddad, F. (2020). Interaction between Fusarium oxysporum $\mathrm{f}$. sp. cubense and Radopholus similis can lead to changes in the resistance of banana cultivars to Fusarium wilt. European Journal of Plant Pathology. https://doi.org/10.1007/s10658-020-02081-y.

Rodgers-Gray, B. S., \& Shaw, M. W. (2000). Substantial reductions in winter wheat diseases caused by addition of straw but not manure to soil. Plant Pathology, 49(5), 590-599. https://doi.org/10.1046/j.1365-3059.2000.00497.x.

Segura, R. A., Serrano, E., Pocasangre, L., Acuña, O., Bertsch, F., Stoorvogel, J. J., \& Sandoval, J. A. (2015). Chemical and microbiological interactions between soils and roots in commercial banana plantations (Musa AAA, cv. Cavendish). Scientia Horticulturae, 197, 66-71. https://doi.org/10.1016 j.scienta.2015.10.028.

Segura, R. A., Stoorvogel, J. J., Bosman, M., \& Sandoval, J. A. (2019). Fusarium wilt (Foc race 1) in relation to soil properties in smallholder's farms with 'Gros Michel' banana (Musa AAA) in Costa Rica. CORBANA, 45(65), 67-82.
Segura, R. A., Stoorvogel, J. J., Samuels, J. Z., \& Sandoval, J. A. (2018). Managing the interactions between soil abiotic factors to alleviate the effect of Fusarium wilt in bananas. Acta Horticulturae, (1196), 163-168. https://doi.org/10.17660 /ActaHortic.2018.1196.19.

Smith, L. J., Smith, M. K., Tree, D., O’Keefe, D., \& Galea, V. J. (2008). Development of a small-plant bioassay to assess banana grown from tissue culture for consistent infection by Fusarium oxysporum f. sp. cubense. Australasian Plant Pathology, 37(2), 171. https://doi.org/10.1071/AP08006.

Stoorvogel, J. J., \& Segura, R. A. (2018). Nutrition and soil management in banana cultivation. In Wageningen University and research, the Netherlands \& G. H. J. Kema (Eds.), Burleigh Dodds Series in Agricultural Science (pp. 223-234). Burleigh Dodds science publishing. https://doi. org/10.19103/AS.2017.0020.16.

Stover, R. H. (1961). Studies on Fusarium wilt of bananas. I. Field Control. Canadian Journal of Botany, 39(1), 197-206.

Tiedemann, A. V. (1995). Single and combined effects of nitrogen fertilizations and ozone on fungal leaf diseases on wheat. Journal of Plant Diseases and Proctection, 103(4), 409-419.

Walters, D. R., Paul, N. D., \& Ayres, P. G. (1984). Effects of mildew and nitrogen on grain yield of barley Artifically infected in the field. Annals of Botany, 54(1), 145-148. https://doi.org/10.1093/oxfordjournals.aob.a086768. 